\title{
APLIKASI BUBUK (POWDER) ZAT WARNA ALAMI KULIT BUAH KAKAO (Theobroma cacao Spp) PADA PEWARNAAN BATIK KATUN
}

\author{
Application of Natural Dye Powder from Cocoa Pod Husk Waste \\ on Cotton Batik
}

\author{
Isnaini, Guring Briegel Mandegani, Masiswo, Agus Haerudin, Vivin Atika, Dwi Wiji Lestari, \\ Tin Kusuma Arta, dan Yudi Satria \\ Balai Besar Kerajinan dan Batik \\ Jl. Kusumanegara 7, Yogyakarta \\ e-mail: gbmandegani@gmail.com
}

\begin{abstract}
Indonesian chocolate industry reached a total production of more than 500 thousand tons. The remaining cocoa pod husk reaches almost $75 \%$ of the total weight of cocoa which has the potential to be used as feed, adsorbent, or others. This study aims to determine the color quality of the cocoa pod husk powder (LKBK) on cotton batik. The experimental steps carried out were extraction, drying with the addition of maltodextrin (spray-drying process), and applying natural dyes to cotton cloth with fixation of alum, lime and ferrous sulfate. The variables carried out were variations in extraction temperature $\left(60,80\right.$ and $\left.100{ }^{\circ} \mathrm{C}\right)$, extraction $\mathrm{pH}$ conditions (neutral, acidic and alkaline), the amount of maltodextrin (5, 10 and 15\%), as well as final mordan alum, lime, and ferrous sulfate. The results of the experiment showed that the color direction varied in each treatment. The color direction at high extraction temperature $100{ }^{\circ} \mathrm{C}-5 \%$ maltodextrin-ferrous sulfate fixators will produce darker color than other treatments. The color fastness test results were found to be quite stable at 45 point (category: good).
\end{abstract}

Keywords: cacao husk, spray drying, batik, maltodextrin, cotton

Abstrak: Industri cokelat di Indonesia mencapai jumlah produksi lebih 500 ribu ton. Jumlah tersebut menyisakan sisa kulit buah dengan jumlah hampir mencapai $75 \%$ dari total berat kakao yang berpotensi untuk dimanfaatkan menjadi pakan, adsorben, ataupun yang lainnya. Penelitian ini bertujuan untuk mengetahui kualitas warna powder limbah kulit buah kakao (LKBK) pada kain batik katun Perlakuan yang dilakukan yaitu ekstraksi, pengeringan dengan penambahan variasi maltodekstrin (proses spray-drying), dan aplikasi zat warna alami pada kain katun dengan fiksasi tawas, kapur dan tunjung. Variabel yang dilakukan adalah variasi suhu ekstraksi (60, 80 dan $100{ }^{\circ} \mathrm{C}$ ), kondisi pH ekstraksi (netral, asam dan basa), jumlah maltodekstrin (5, 10 dan 15\%), serta mordan akhir tawas, kapur, dan tunjung. Hasil penelitian menunjukkan arah warna yang bervariasi pada

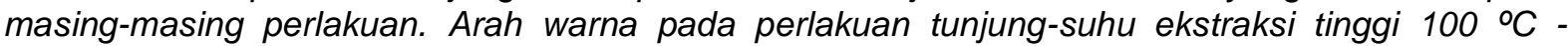
maltodekstrin 5\% menghasilkan warna yang lebih gelap dibandingkan perlakuan yang lainnya. Hasil uji ketahanan luntur yang diperoleh cukup stabil yakni nilai 4-5 (kategori baik).

Kata kunci: kulit buah kakao, spray drying, batik, maltodekstrin, katun

\section{PENDAHULUAN}

Kakao merupakan salah satu komoditi hasil perkebunan yang mempunyai peran cukup penting dalam kegiatan perekonomian di Indonesia. Kakao (Theobroma cacao) mencatatkan hasil ekspor pada tahun 2018 mencapai 288.935 ton setara dengan 706 juta USD. Indonesia merupakan negara produsen dan eksportir kakao terbesar keenam dunia setelah Ghana dan Pantai Gading (International Cocoa Organization, 2020). Produksi kakao dalam negeri mencapai jumlah produksi 577.039 ton didukung dengan luas area perkebunan mencapai 1.661.700 Ha (Badan Pusat Statistik Indonesia, 2019).

Pengolahan buah kakao untuk menghasilkan produk cokelat dengan melalui proses fermentasi biji. Limbah kulit buah kakao (LKBK) memiliki karakteristik yang berupa selulosa selulosa $36,23 \%$, hemiselulosa $1,14 \%$ dan lignin 20,0027,95\% (Direktorat Jendral Perkebunan, 2016). Kulit buah kakao memiliki potensi 
limbah sebesar $75 \%$ (Puastuti dan Susana, 2014). Limbah kulit buah kakao kemudian dimanfaatkan sebagai pakan ternak kambing, babi, entog dan ayam dengan cara fermentasi (Bursatriannyo, 2014), (Kamelia dan Fathurohman, 2017). Limbah kulit buah kakao juga dimanfaatkan untuk bioabsorben ion logam Ni (II) (Malimongan et al., 2015), bioabsorben Rhodamin B (Purnamawati dan Utami, 2014), bahan baku zat warna $\beta$ karoten (Wulan, 2001), bahan pewarna batik (Pujilestari et al., 2016), (Ayuningtyas et al., 2015) dengan cara mengekstrak kulit buah kakao melalui proses rebusan. Penggunaan limbah kulit buah kakao menunjukkan adanya potensi dari limbah perkebunan yang bisa dimanfaatkan ulang untuk produk kerajinan tekstil.

Pemanfaatan limbah kulit buah kakao yang dilakukan oleh Pujilestari et al. (2016), dan Ayuningtyas et al. (2015) menggunakan metode ekstraksi rebusan kulit kakao. Ekstraksi merupakan cara memperoleh sari dari suatu material menggunakan pelarut dengan hasil produk yang disebut ekstrak. Ekstraksi didasarkan pada sifat kelarutan suatu bahan terhadap komponen lainnya dalam campuran. Ekstraksi berdasarkan suhu dibagi menjadi 2 yaitu cara panas dengan perebusan, infundasi, seduhan, refluks, sokletasi dan cara dingin: maserasi, maserasi kinetik, perkolasi (Sudjadi, 1988).

Ekstrak yang diperoleh kemudian diberi perlakuan powderized atau menjadi bubuk dengan menggunakan alat spray dryer. Spray drying (pengeringan semprot) merupakan teknik yang banyak diaplikasikan untuk menyalut komponen flavor dan juga pewarna alami. Teknik ini telah digunakan secara luas karena memiliki berbagai keunggulan antara lain ketersediaan peralatan, beragamnya pilihan bahan penyalut, ukuran partikel kapsul dan dispersibilitasnya untuk hampir semua aplikasi pangan, serta tingkat retensi dan stabilitas bahan volatil yang baik (Sofyaningsih dan Iswahyudi, 2018). Penggunaan alat spray dryer dapat mengeringkan ekstrak cair pewarna alami dari limbah kakao. Pengeringan adalah salah satu cara untuk mengurangi jumlah kandungan air di dalam suatu bahan dengan cara menguapkan air tersebut dengan menggunakan energi panas sehingga kadar air menurun dan akan memperlambat laju kerusakan ekstrak limbah kakao akibat aktivitas biologi maupun kimia (Padmitasari dan Novitasari, 2010).

Penelitian ini bertujuan untuk mengetahui hasil pewarnaan kain katun dengan teknik batik menggunakan bubuk pewarna alami yang berasal dari limbah kulit kakao.

\section{METODOLOGI}

Penelitian ini menggunakan metode eksperimental. Metode yang digunakan adalah modifikasi dari percobaan yang dilakukan Pujilestari (2016) dengan variasi perlakuan yaitu suhu ekstraksi $(60,80$ dan $100 \stackrel{\circ}{\circ}$ ), waktu ekstraksi (1, 2 dan 3 jam), $\mathrm{pH}$ pelarut air (4 (asam), 10 (basa) dan 7 (netral), konsentrasi filler maltodekstrin (5, 10 dan 15\%) jenis kain katun, serta fiksasi tawas, kapur dan tunjung.

\section{Bahan dan Alat}

Penelitian ini menggunakan bahan kulit buah kakao dari perkebunan kakao di Patuk (Gunung Kidul, Yogyakarta), air, kapur, tawas (aluminium sulfat/ $\mathrm{Al}_{2}\left(\mathrm{SO}_{4}\right)_{3}$ ), tunjung (fero sulfat/ $/ \mathrm{FSO}_{4}$ ), soda abu $\left(\mathrm{Na}_{2} \mathrm{CO}_{3}\right.$ ), TRO (Turkey Red Oil/Sulfated Castor Oi), dan maltodektrin.

Peralatan yang digunakan diantaranya ember pencelupan, bak pelorodan, pisau pencacah, penyaring, gelas ukur, gayung, pengukur $\mathrm{pH}$, laundero-meter Original Hanau, gray scale merek SDC, staining scale merek SDC, spektrofotometer UV-Vis Shimadzu 2401 (PC) S, colorimeter portable AMT 50, serta spray-dryer (Spray dryer GEA Niro - Balai Besar Industri Agro, Bogor).

\section{Prosedur Kerja \\ Persiapan Bahan dan Alat}

Kulit buah kakao basah dicuci bersih, kemudian dicacah sampai berukuran maksimal $3 \times 4 \mathrm{~cm}$ menggunakan pisau atau parang. Cacahan kulit buah kakao dikukus pada suhu $100 \stackrel{\circ}{\circ}$ selama 5 menit pada panci pengukus. Kulit buah kakao basah yang sudah dikukus kemudian direndam di dalam larutan asam oksalat pada suhu kamar selama 15 menit untuk mempertahankan kondisi segar kulit kakao, kemudian dibilas dengan air sampai bersih.

\section{Ekstraksi}


Ekstraksi dilakukan dengan cara yang dimodifikasi dari Susanto (1973) dan Mansour (2018). Kulit buah kakao basah yang telah dibersihkan, diekstraksi dengan perbandingan $1 \mathrm{~kg}$ bahan: 5 liter air, dengan variasi suhu $\left(60,80\right.$, dan $\left.100^{\circ} \mathrm{C}\right)$; durasi ekstraksi selama 3 jam); dan variasi kondisi derajat keasaman $(\mathrm{pH})$ asam, basa dan netral.

\section{Pembuatan bubuk zat warna alami (proses pembubukan)}

Larutan hasil ekstraksi kemudian dilakukan proses pembuatan bubuk zat warna alami. Larutan diolah dengan menambahkan filler maltodekstrin dengan variasi $5 \%$ (50 g/L), 10\% (100 g/L), dan 15\% $150 \mathrm{~g} / \mathrm{L})$. Larutan dibubukkan dengan spray dryer pada suhu inlet $240^{\circ} \mathrm{C}$ dan suhu outlet $80-85^{\circ} \mathrm{C}$.

\section{Pengujian kualitas warna}

Pengujian kualitas warna dilakukan dengan 3 parameter yakni (1) ketuaan warna dilakukan dengan metode perhitungan nilai $\mathrm{K} / \mathrm{S}$ melalui pengukuran nilai reflaktansi (\%R) pada panjang gelombang maksimal setiap warna. Nilai ini digunakan untuk mendapatkan penilaian kualitatif pada pewarna (Ahmed et al., 2006); (2) pengujian arah warna menggunakan metode CIELAB untuk mengetahui kecenderungan warna yang dihasilkan dengan nilai $L^{*}=$ arah warna hitam (nilai 0) dan putih (nilai 100), nilai $a^{*}$ (hijau sampai merah, dan nilai $b^{*}$ (kuning sampai hijau) (Sinaga, 2019); (3) pengujian ketahanan luntur warna terhadap pencucian menggunakan SNI ISO 105-C06: 2010.

\section{Pencelupan}

Proses pencelupan dan pewarnaan kain katun dilakukan dengan beberapa tahap pada Gambar 1. (modifikasi Susanto (1973)). 


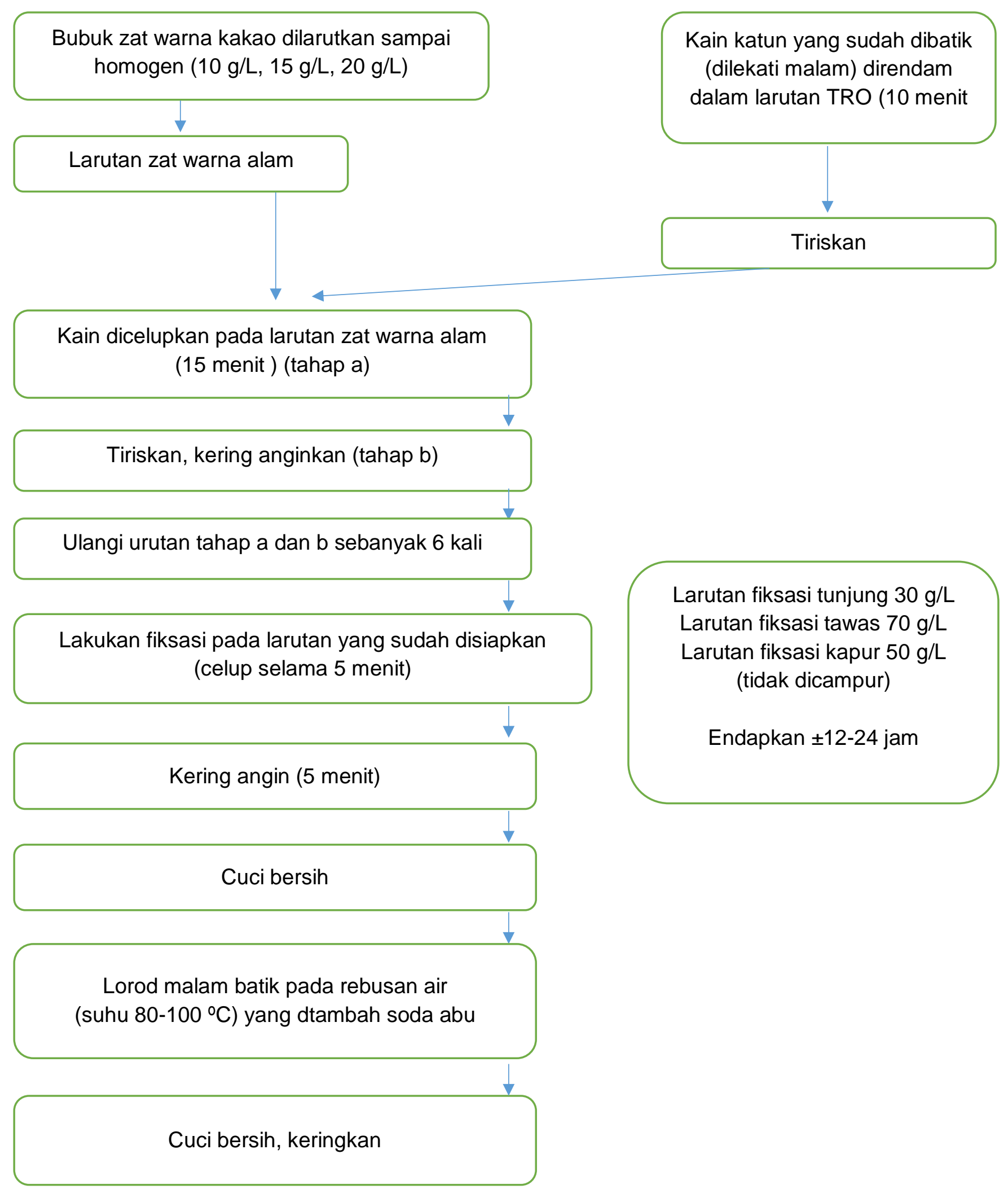

Gambar 1. Bagan alir proses pencelupan kain batik katun pada zat warna alami LKBK

\section{HASIL DAN PEMBAHASAN}

Hasil Pewarnaan Batik

Hasil pewarnaan kain batik katun menggunakan zat warna alami dari LKBK dengan perlakuan fiksator tawas, kapur, dan tunjung dapat dilihat pada Tabel 1, 2, dan 3. 
Tabel 1. Hasil pewarnaan kain batik katun menggunakan zat pewarna alami (LKBK) dengan perlakuan fiksator tawas

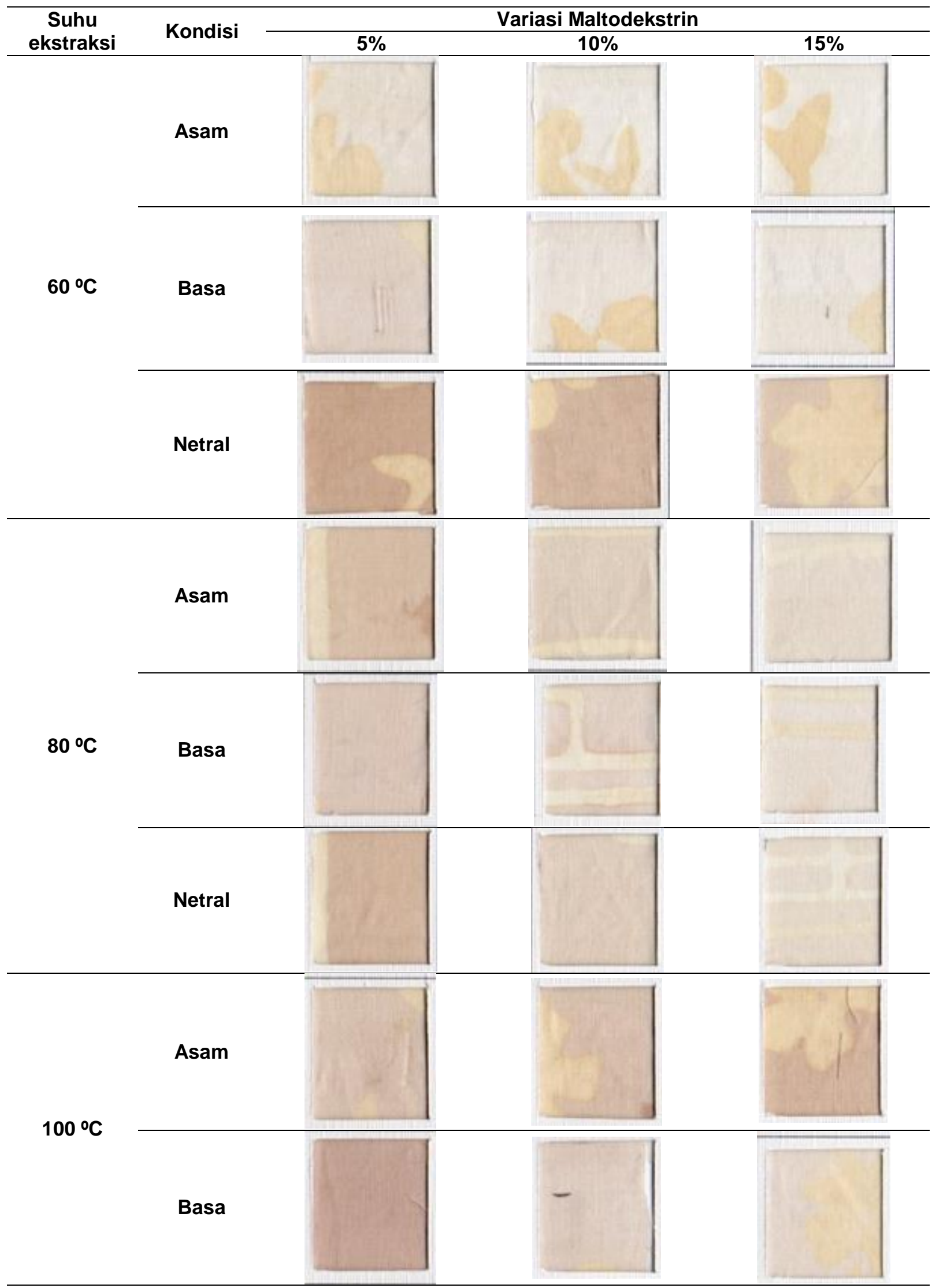




\begin{tabular}{|c|c|c|c|c|}
\hline \multirow{3}{*}{$\begin{array}{c}\text { Suhu } \\
\text { ekstraksi }\end{array}$} & \multirow{2}{*}{ Kondisi } & \multicolumn{3}{|c|}{ Variasi Maltodekstrin } \\
\hline & & $5 \%$ & $10 \%$ & $15 \%$ \\
\hline & Netral & & & \\
\hline
\end{tabular}

Tabel 2. Hasil pewarnaan kain batik katun menggunakan zat pewarna alami (LKBK) dengan perlakuan fiksator kapur






\begin{tabular}{|c|c|c|c|c|}
\hline \multirow{3}{*}{$\begin{array}{c}\text { Suhu } \\
\text { ekstraksi }\end{array}$} & \multirow{2}{*}{ Kondisi } & \multicolumn{3}{|c|}{ Variasi Maltodekstrin } \\
\hline & & $5 \%$ & $10 \%$ & $15 \%$ \\
\hline & Netral & & & \\
\hline
\end{tabular}

Tabel 3. Hasil pewarnaan kain batik katun menggunakan zat pewarna alami (LKBK) dengan perlakuan fiksator tunjung

\begin{tabular}{|c|c|c|c|c|}
\hline \multirow{2}{*}{$\begin{array}{c}\text { Suhu } \\
\text { ekstraksi }\end{array}$} & \multirow{2}{*}{ Kondisi } & \multicolumn{3}{|c|}{ Variasi Maltodekstrin } \\
\hline & & $5 \%$ & $10 \%$ & $15 \%$ \\
\hline \multirow[b]{2}{*}{$60 \stackrel{\circ}{C}$} & Asam & & & \\
\hline & Basa & & & \\
\hline & Netral & & & \\
\hline \multirow{3}{*}{$80 \stackrel{\circ}{C}$} & Asam & & & \\
\hline & Basa & & & \\
\hline & Netral & & & \\
\hline \multirow{2}{*}{$100 \stackrel{\circ}{C}$} & Asam & & & \\
\hline & Basa & & & \\
\hline
\end{tabular}




\begin{tabular}{|c|c|c|c|c|}
\hline \multirow{2}{*}{$\begin{array}{c}\text { Suhu } \\
\text { ekstraksi }\end{array}$} & \multirow{2}{*}{ Kondisi } & \multicolumn{3}{|c|}{ Variasi Maltodekstrin } \\
\hline & & $5 \%$ & $10 \%$ & $15 \%$ \\
\hline & Netral & & & \\
\hline
\end{tabular}

Dari Tabel 1 s.d. 3 terlihat ada perbedaan dari serapan warna pada masing-masing suhu ekstraksi. Pada Tabel 1, kain dengan mordan tawas, memberikan hasil warna yang relatif lebih coklat muda. Pada suhu $60{ }^{\circ} \mathrm{C}$, warna yang dihasilkan hampir mendekati putih, akan tetapi pada kondisi netral, warna yang dihasilkan mulai lebih gelap dibandingkan dengan kondisi asam maupun basa. Arah warna coklat tua pada kondisi netral juga berlaku pada suhu $80 \stackrel{\circ}{ } \mathrm{C}$ dan $100 \stackrel{\circ}{\circ}$. Pada Tabel 2 , hasil kain katun dengan pewarnaan bubuk LKBK dengan fiksator kapur, menunjukkan adanya perbedaan arah warna pada masing-masing perlakuan. Arah warna pada perlakuan suhu $60 \stackrel{\circ}{\circ}$ memperlihatkan warna yang lebih cerah dari perlakuan suhu $100^{\circ} \mathrm{C}$. Pada suhu $80 \stackrel{\circ}{\mathrm{C}}$ arah warna yang dihasilkan relatif sama, baik pada kondisi asam, basa, maupun netral, meskipun pada kondisi asam dan maltodekstrin 5\%, warna yang dihasilkan lebih gelap. Pada kondisi suhu tinggi $\left(100^{\circ} \mathrm{C}\right)$, zat warna yang dihasilkan mampu mewarnai kain dengan lebih intens dibandingkan pada suhu yang lebih rendah $\left(60{ }^{\circ} \mathrm{C}\right)$.

Tabel 3 memperlihatkan hasil perlakuan pewarnaan kain batik katun dengan bubuk LKBK yang menggunakan mordan tunjung, arah warna yang dihasilkan lebih gelap dibandingkan perlakuan mordan tawas atau kapur. Mordan tawas cenderung memberikan warna yang alami, sedangkan pada tunjung cenderung ke arah yang lebih gelap. Hasil pewarnaan dengan bubuk LKBK suhu $60 \stackrel{\circ}{\circ}$ warna yang dihasilkan relatif cerah atau muda, baik pada kondisi asam, basa maupun netral. Penambahan suhu ekstraksi $80^{\circ} \mathrm{C}$ memberikan pengaruh pada arah warna yang lebih gelap dan pada suhu $100 \stackrel{\circ}{\circ}$, warna lebih gelap lagi dibandingkan dengan suhu 80 ․ $\mathrm{C}$. Penggunaan maltodekstrin pada bubuk LKBK memberikan pengaruh pada arah warna yang dihasilkan. Semakin banyak maltodekstrin, arah warna yang dihasilkan semakin muda seperti terlihat pada Tabel 1 s/d 3, hal ini memberikan informasi bahwa zat warna pada bubuk LKBK dengan maltodekstrin dengan konsentrasi yang tinggi, maka konsentrasi zat warna alami yang terikat akan semakin rendah.

Penggunaan maltodekstrin sebagai filler bertujuan untuk meningkatkan total padatan dalam bahan yang dikeringkan, dimana semakin banyak bahan pengisi yang ditambahkan akan menurunkan kadar air. Semakin banyak penambahan maltodekstrin, kadar airnya semakin menurun (Utomo, 2013). Maltodekstrin memiliki karakteristik sifat mampu mengikat kadar air bebas suatu bahan, sehingga dengan penambahan maltodekstrin yang semakin banyak dapat menurunkan kadar air produk (Hui, 2006). Pada penelitian pewarna daun suji, penggunaan maltodekstrin meningkatkan rendemen dari proses pembubukan (Tama et al., 2014). 
Ketuaan warna

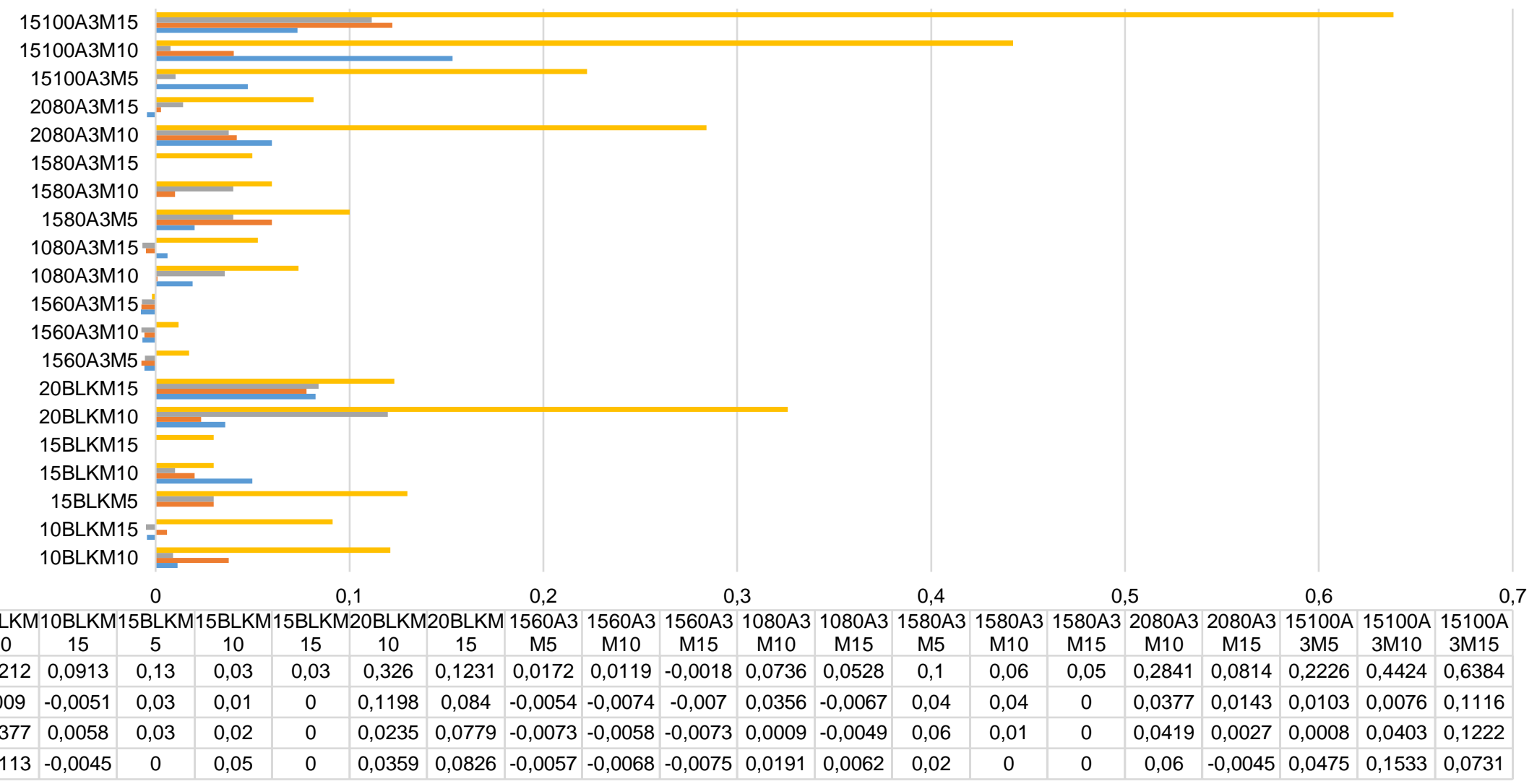

Gambar 2. Grafik nilai ketuaan warna pewarnaan powder limbah kulit kakao pada kain batik katun pada kondisi asam dan blanko Keterangan:

Kode 15 T60 A 3 M5 menunjukkan

$15 \quad: 15$ gram per liter bubuk zat warna alami pada aplikasi kain 
Jurnal Industri Hasil Perkebunan Vol.15 No.2 Desember 2020: 75-93

T60/80/100 : 60/80/100 9 C kondisi suhu ekstraksi

A/B : kondisi asam/basa

$3 \quad: 3$ jam waktu ekstraksi

M5/10/15 : konsentrasi maltodekstrin

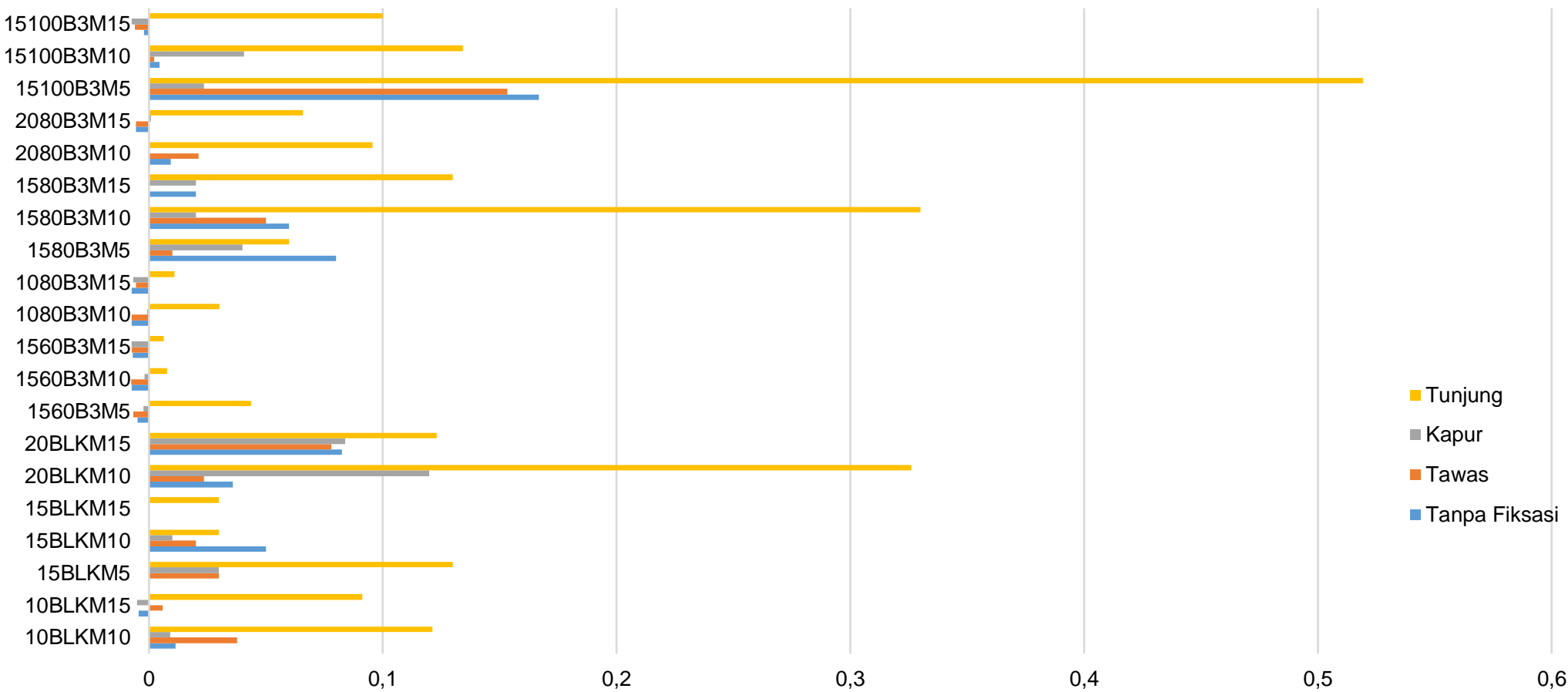

$-0,1$

0

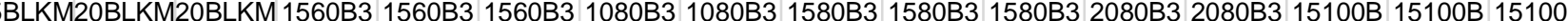

\begin{tabular}{|c|c|c|c|c|c|c|c|c|c|c|c|c|c|c|c|c|c|c|c|c|}
\hline & 10 & 15 & 5 & 10 & 15 & 10 & 15 & M5 & M10 & M15 & M10 & M15 & M5 & M10 & M15 & M10 & M15 & 3M5 & $3 \mathrm{M} 10$ & 3M15 \\
\hline Tunjung & 0,1212 & 0,0913 & 0,13 & 0,03 & 0,03 & 0,326 & 0,1231 & 0,0437 & 0,0077 & 0,0063 & 0,0302 & 0,0109 & 0,06 & 0,33 & 0,13 & 0,0955 & 0,0659 & 0,5194 & 0,1342 & 0,1 \\
\hline$\approx$ Kapur & 0,009 & $-0,0051$ & 0,03 & 0,01 & 0 & 0,1198 & 0,084 & $-0,0023$ & $-0,0018$ & $-0,0073$ & $-0,0007$ & $-0,0067$ & 0,04 & 0,02 & 0,02 & $-0,0003$ & 0,0009 & 0,0236 & 0,0406 & $-0,0074$ \\
\hline - Tawas & 0,0377 & 0,0058 & 0,03 & 0,02 & 0 & 0,0235 & 0,0779 & $-0,0066$ & $-0,0076$ & $-0,0074$ & $-0,0075$ & $-0,0055$ & 0,01 & 0,05 & 0 & 0,0212 & $-0,0056$ & 0,1533 & 0,0021 & $-0,0061$ \\
\hline - Tanpa Fiksasi & 0,0113 & $-0,0045$ & 0 & 0,05 & 0 & 0,0359 & 0,0826 & $-0,0048$ & $-0,0074$ & $-0,007$ & $-0,0074$ & $-0,0073$ & 0,08 & 0,06 & 0,02 & 0,0094 & $-0,0056$ & 0,1667 & 0,0045 & $-0,0022$ \\
\hline
\end{tabular}

Gambar 3. Grafik nilai ketuaan warna pewarnaan powder limbah kulit kakao pada kain batik katun pada kondisi basa dan blanko 


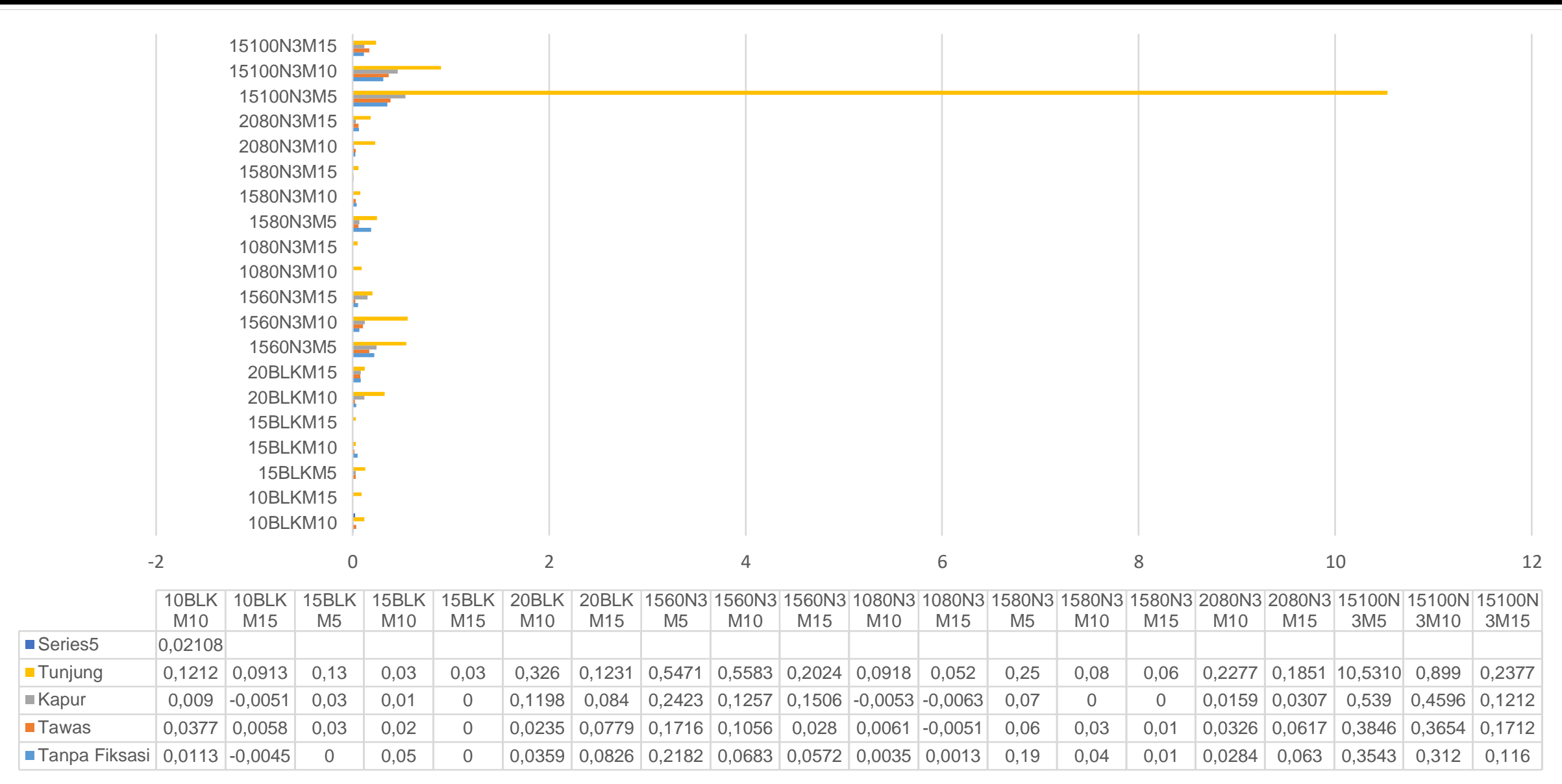

Gambar 4. Grafik nilai ketuaan warna pewarnaan powder limbah kulit kakao pada kain batik katun pada kondisi netral dan blanko 
Pengujian ketuaan warna pada kain dilakukan untuk mengetahui besaran serapan zat warna pada kain. Nilai serapan warna dihasilkan dari cahaya yang dipantulkan oleh kain dan dilambangkan dengan nilai K/S. Semakin tinggi nilai K/S, maka warna akan semakin mendekati gelap karena banyak zat warna yang terserap, sedangkan semakin rendah nilai K/S, maka larutan zat warna yang terserap sedikit (Lutfinor, 2011 dan Kuntari, 2006). Suhu hasil ekstraksi memiliki pengaruh dalam memberikan nilai $\mathrm{K} / \mathrm{S}$, semakin tinggi suhu ekstraksi, memberikan nilai lebih tinggi daripada suhu ekstraksi yang rendah. Menurut Satria dan Suheryanto (2016), semakin tinggi suhu maka semakin tinggi panjang gelombang dari warna yang dihasilkan pada kain. Selain itu, pada penelitian yang dilakukan oleh Razak, et al., (2011), menunjukkan adanya korelasi antara kenaikan suhu air dengan senyawa kepolaran rendah, seperti purpurin. Ketika suhu air tinggi, maka akan mempengaruhi polaritas air yang kemudian mempermudah pelarutan senyawa pada kandungan kimia zat warna alami pada material. Senyawa katekin pada kulit kakao yang memiliki sifat polar, juga akan bersifat sama dengan purpurin.

Kondisi asam pada proses ekstraksi (Gambar 2) menunjukkan hasil pewarnaan bubuk yang bervariasi. Gambar 2 terlihat bahwa ada beberapa perlakuan dengan nilai K/S yang rendah, bahkan cenderung minus. Selain itu, terlihat juga adanya nilai K/S yang relatif tinggi yakni pada perlakuaan dengan mordan tunjung yang memiliki logam $\mathrm{Fe}$. Secara umum, zat warna bubuk limbah kulit buah kakao, mampu memberikan warna dengan intensitas yang berbeda. Nilai K/S tertinggi pada bubuk ZWA limbah kulit buah kakao kondisi asam ada pada perlakuan 15 gram per liter dengan suhu ekstraksi $100 \stackrel{\circ}{ } \mathrm{C}$ selama 3 jam maltodekstrin $15 \%$. Semakin banyak penggunaan bubuk LKBK akan menambah ketuaan warna dari LKBK. Pada mordan tawas (Al), kapur ( $\mathrm{Ca}$ ) dan tunjung ( $\mathrm{Fe}$ ), nilai K/S pada perlakuan tersebut samasama tinggi, akan tetapi pada mordan kapur, nilai K/S sedikit lebih rendah daripada pada blanko dengan kadar pewarnaan 20 gram per liter. Nilai K/S pada perlakuan ekstraksi suhu $60^{\circ} \mathrm{C}$ relatif rendah, hal ini disebabkan senyawa zat warna belum banyak terekstrak sehingga berpengaruh pada kualitas ketuaan warna yang terserap pada kain.

Hasil ekstraksi pada kondisi basa bubuk LKBK (Gambar 3) terlihat nilai K/S tertinggi pada perlakuan 15 gram dengan suhu ekstraksi $100 \stackrel{\circ}{\circ}$ dengan nilai K/S 0,5194. Nilai pada perlakuan tersebut dilakukan pada mordan tunjung, sedangkan pada mordan tawas dan kapur nilai K/S hanya 0,1667 (tawas) dan 0,0406 (kapur). Pada Gambar 4, perlakuan dilakukan pada suhu netral, dengan hasil nilai K/S tertinggi diperoleh pada perlakukan 15 gram per liter pada suhu $100{ }^{\circ} \mathrm{C}$ selama 3 jam dengan penambahan maltodekstrin $5 \%$. Nilai tertinggi didapatkan pada perlakuan mordan tunjung dibandingkan dengan tawas dan kapur. Nilai K/S pada perlakuan $15 \mathrm{gpl} / 100 / \mathrm{N} 3 / \mathrm{m} 5 \%$ sangat tinggi sekali sehingga terlihat menonjol dibandingkan perlakuan lainnya yang relatif memiliki nilai rendah dengan perbedaan yang kecil. Perlakuan asam, basa, dan netral, dilakukan untuk melihat pengaruh kondisi ekstrasi pada LKBK (limbah kulit buah kakao) pada flavanoid maupun tanin yang terekstrak (Lestari, et al., 2020). Mayoritas pewarna alami yang berupa tanin dengan sifat yang asam, menyebabkan sifat tersebut mudah terekstrak dengan cara peningkatan kadar keasaman pada proses ekstraksi (Ali, et al., 2016).

\section{Beda warna}

Analisis perbedaan dilakukan dengan metode CIE-LAB. Dengan metode tersebut, akan diketahui hasil pengukuran warna dari masingmasing perlakuan. Adapun hasil pengukuram ditampilkan pada Gambar 5 sampai dengan Gambar 7. 


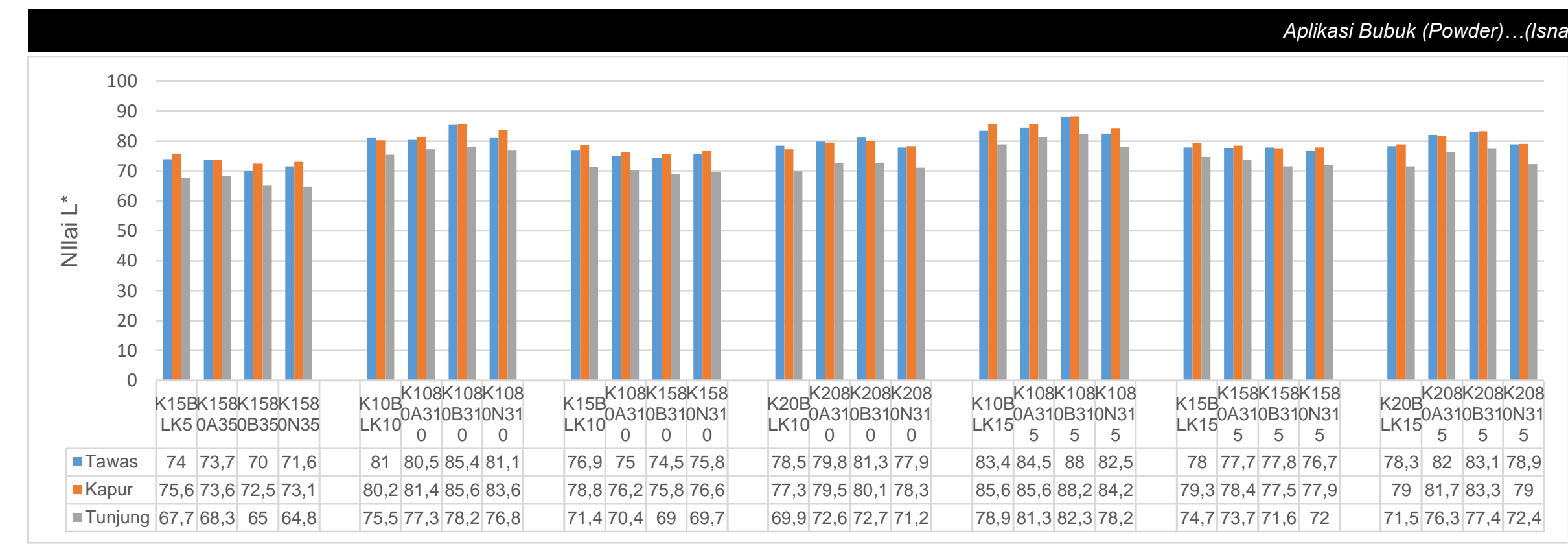

Gambar 5. Grafik nilai L* sampel 


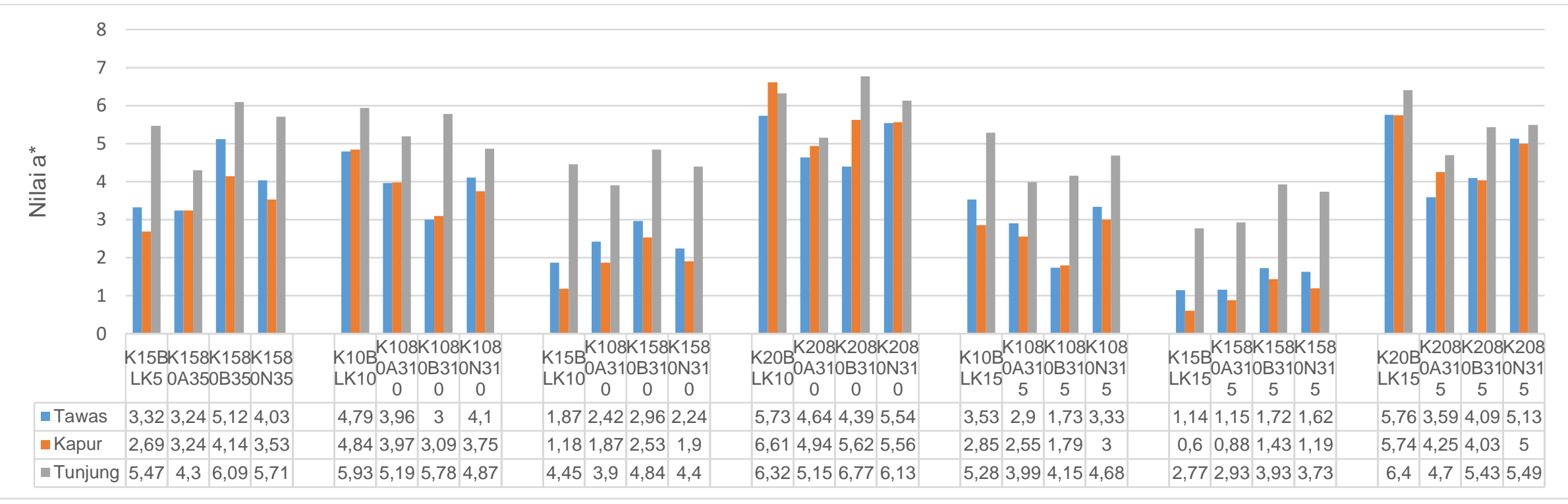

Gambar 6. Grafik nilai a* pada sampel 


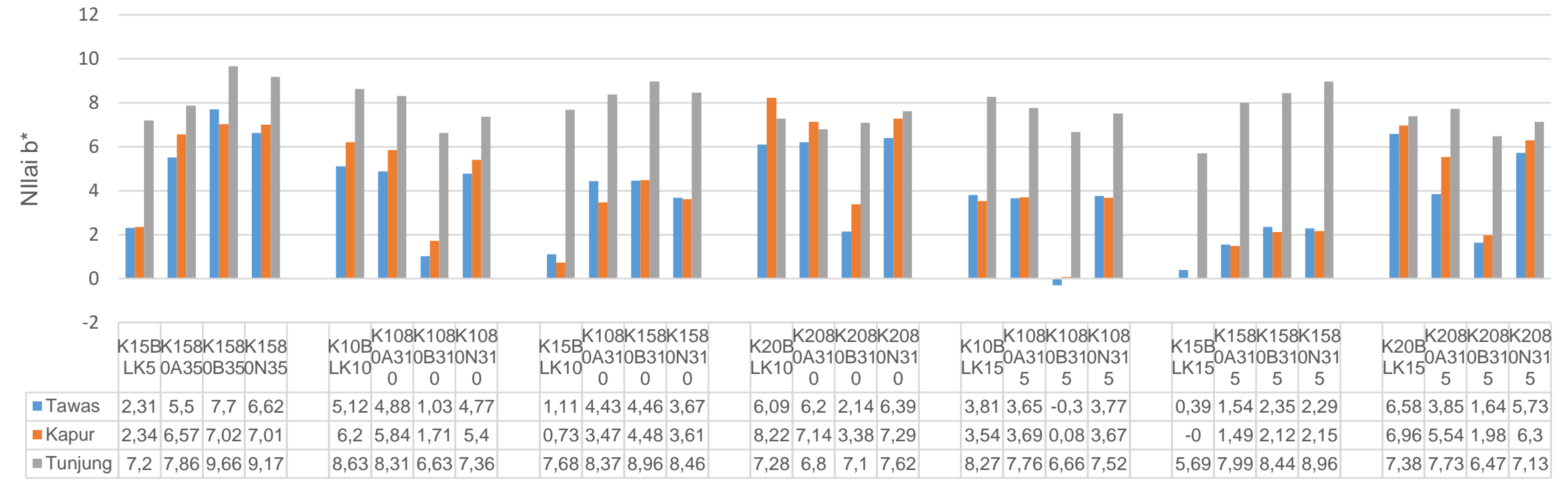

Gambar 7. Grafik nilai b* pada sampel

Perbedaan warna pada masing-masing perlakuan campuran biru-kuning dengan nilai $-b^{*}(-70 \mathrm{~s} / \mathrm{d} 0$; biru $) \mathrm{dan}+\mathrm{b}^{*}(0$ pewarnaan dengan bubuk limbah kulit buah kakao (LKBK) s/d +70; kuning). Hasil pewarnaan LKBK menghasilkan warna yang ditunjukkan pada Gambar $5 \mathrm{~s} / \mathrm{d} 7$ dengan nilai $L^{*}$, $a^{*}$ dan $b^{*}$. Nilai $L^{*}$ bervariasi dengan nilai yang positif baik pada $L^{*}$, $a^{*}$,maupun $b^{*}$. merupakan segmentasi warna yang menunjukkan nilai warna Penggunaan maltodekstrin dengan variasi $5 \mathrm{~s} / \mathrm{d} 15 \%$ juga akromatik putih yang dihasilkan dari cahaya pantul. Nilai $L^{*}$ berupa menunjukkan hasil yang relatif sama, tidak ada perbedaan yang angka 0 (hitam) sampai dengan 100 (putih). Nilai a* menunjukkan menonjol pada Gambar $4 \mathrm{~s} / \mathrm{d} 6$. Nilai rerata hasil CIE-LAB pada arah warna hijau (-a*; $-80 \mathrm{~s} / \mathrm{d}$ 0) sampai dengan merah $\left(+\mathrm{a}^{*} ; 0 \mathrm{~s} / \mathrm{d} \quad\right.$ ditampilkan pada Tabel 4.

$+80)$, sedangkan nilai $b^{*}$ merupakan notasi warna kromatik

Tabel 4. Rata-rata nilai CIE-LAB

\begin{tabular}{lcccc}
\multicolumn{5}{c}{ Tabel 4. Rata-rata nilai CIE-LAB } \\
\hline \multicolumn{1}{c}{ Mordan } & $\mathrm{L}^{*}$ & $\mathrm{a}^{*}$ & $\mathrm{~b}^{*}$ & $\begin{array}{c}\text { Pantone® }{ }^{\circledR} \text { FHI Cotton TCX } \\
\text { Color Library }\end{array}$ \\
\hline Tawas (aluminium sulfat) & 78,85 & 3,47 & 3,85 & Pumice Stone \\
Kapur (kalsium oksida) & 79,57 & 3,31 & 4,21 & Moonbeam \\
Tunjung (fero sulfat) & 73,25 & 4,96 & 7,75 & Mushroom \\
\hline
\end{tabular}


Tabel 4, memperlihatkan bahwa nilai $L^{*}$ yang bersifat hitam (0) - putih (100) pada perlakuan tunjung cenderung lebih rendah $(73,25)$ daripada tawas $(78,85)$ dan kapur $(79,57)$. Sifat mordan tawas dan kapur menghasilkan warna yang lebih natural dan lebih cerah dibandingkan mordan tunjung. Nilai $a^{*}$ dan $b^{*}$ pada kain memperlihatkan tunjung memiliki arah warna yang cenderung gelap (coklat-kehijauan) daripada tawas dan kapur dengan arah warna salem-kuning-merah muda (Tabel $1 \mathrm{~s} / \mathrm{d}$ Tabel 3).

\section{Ketahanan luntur warna terhadap pencucian}

Pengujian tahan luntur warna pada kain batik katun dengan pewarnaan bubuk limbah kulit buah kakao, dapat dilihat pada Tabel 5.

Tabel 5. Ketahanan luntur warna terhadap pencucian

\begin{tabular}{ccccc}
\hline Kode sampel & Tanpa Fiksasi & Tawas & Kapur & Tunjung \\
\hline 10-BLK-M10 & $4-5$ & 4 & $4-5$ & $4-5$ \\
10-BLK-M15 & $4-5$ & $4-5$ & $4-5$ & $4-5$ \\
15-BLK-M10 & $4-5$ & $4-5$ & $4-5$ & $4-5$ \\
15-BLK-M15 & $4-5$ & $4-5$ & 4 & $4-5$ \\
20-BLK-M10 & $4-5$ & 4 & 4 & 4 \\
20-BLK-M15 & $4-5$ & $4-5$ & $4-5$ & 4 \\
10-80-A3-M10 & $4-5$ & $4-5$ & $4-5$ & $4-5$ \\
10-80-A3-M15 & $4-5$ & $4-5$ & $4-5$ & $4-5$ \\
15-80-A3-M10 & $4-5$ & $4-5$ & $4-5$ & 4 \\
15-80-A3-M15 & $4-5$ & 4 & $3-4$ & 4 \\
20-80-A3-M10 & 4 & 4 & $4-5$ & 4 \\
20-80-A3-M15 & $4-5$ & $4-5$ & 4 & $4-5$ \\
10-80-B3-M10 & $4-5$ & 4 & 4 & $4-5$ \\
10-80-B3-M15 & 4 & $4-5$ & $4-5$ & $4-5$ \\
15-80-B3-M10 & $4-5$ & 4 & 4 & 4 \\
15-80-B3-M15 & 4 & 4 & 3 & 4 \\
20-80-B3-M10 & $4-5$ & $4-5$ & $4-5$ & $4-5$ \\
20-80-B3-M15 & $4-5$ & $4-5$ & $4-5$ & $4-5$ \\
10-80-N3-M10 & $4-5$ & $4-5$ & $4-5$ & $4-5$ \\
10-80-N3-M15 & $4-5$ & $4-5$ & $4-5$ & 4 \\
15-80-N3-M10 & $4-5$ & 4 & $4-5$ & $4-5$ \\
\hline
\end{tabular}




\begin{tabular}{ccccc}
\hline Kode sampel & Tanpa Fiksasi & Tawas & Kapur & Tunjung \\
\hline 15-80-N3-M15 & $3-4$ & 4 & 4 & 4 \\
20-80-N3-M10 & $4-5$ & $4-5$ & $4-5$ & $4-5$ \\
20-80-N3-M15 & 4 & $4-5$ & $4-5$ & $4-5$ \\
& & & & \\
\hline
\end{tabular}

Adapun notasi evaluasi tahan luntur warna ada pada Tabel 6.

Tabel 6. Nilai ketahanan luntur warna

\begin{tabular}{cc}
\hline Nilai tahan luntur warna & Evaluasi tahan luntur warna \\
\hline 5 & Baik sekali \\
$4-5$ & Baik \\
4 & Baik \\
$3-4$ & Cukup baik \\
3 & Cukup \\
$2-3$ & Kurang \\
2 & Kurang \\
$1-2$ & Jelek \\
1 & Jelek \\
\hline
\end{tabular}

Hasil evaluasi ketahanan luntur warna terhadap pencucian pada kain batik katun ditunjukkan dengan notasi angka $4 \mathrm{~s} / \mathrm{d} \mathrm{4-5}$ (pada Tabel 5). Hal tersebut memiliki arti bahwa kualitas pewarnaan termasuk baik. Pewarnaan alami dengan bahan alam, memerlukan mordan logam yang difungsikan untuk proses pengikatan warna pada kain sehingga lebih tahan luntur. Warna alami akan membentuk ikatan dengan logam dan kain secara kompleks sehingga mampu menciptakan proteksi terhadap penurunan kualitas warna secara fotolitik maupun fisik (Lestari et al., 2020).

\section{SIMPULAN}

Penggunaan pewarna bubuk limbah kulit buah kakao pada katun menghasilkan pewarnaan dengan arah warna yang bervariasi. Penggunaan variabel mordan akhir, suhu, kondisi pH pada ekstraksi dan penggunaan maltodekstrin, berpengaruh pada arah warna yang dihasilkan. Hasil uji ketuaan warna dari hasil aplikasi pewarnaan batik kain katun dengan menggunakan powder zat warna alami, nilai yang optimal pada suhu ekstraksi $100^{\circ} \mathrm{C}$, waktu ekstraksi $3 \mathrm{jam}, \mathrm{pH}$ netral, filler maltodekstrin $5 \%$ dan konsentrasi bubuk zat warna $15 \%$. Warna pada kain batik katun dengan bubuk LKBK dengan arah yang 
lebih gelap/tua dihasilkan dengan ekstraksi suhu tinggi $100 \stackrel{\circ}{\circ}$. Notasi nilai $L^{*} a^{*} b^{*}$ pada setiap perlakuan, mengarah pada arah warna salem hingga coklat tua. Variasi percobaan yang beragam, hasil pengujian pada ketahanan luntur terhadap pencucian termasuk pada klasifikasi baik.

\section{DAFTAR PUSTAKA}

1. Ahmed, Niser, David P. Oulton, and John A. Taylor. 2006. "The Use of Reflectance Measurements in the Determination of Fixation of Reactive Dyes to Cotton." Color Research and Application 31 (2): 117-21. https://doi.org/10.1002/col.20189.

2. Ali, Shaukat, Jabeen Sobia, Tanveer Hussain, Sadia Noor, and Umme Habibah Siddiqua. 2016. "Optimization of Extraction Condition of Natural Dye From Pomegranate Peels Using Response Surface Methodology." International Journal of Engineering Sciences \& Research Technology 5 (7): 542-48.

3. Ayuningtyas, Indah Permata, Tiwi Bina Affanti, dan Theresia Widhyastuti. 2015. "Pemanfaatan Kulit Buah Kakao sebagai Pewarna Alami pada Proses Batik." Texfile 2 (1).

4. Badan Pusat Statistik Indonesia. 2019. "Statistik Kakao Indonesia 2018." Jakarta.

5. Bursatriannyo. 2014. "Pemanfaatan Kulit Kakao Untuk Pakan Ternak Pusat Penelitian dan Pengembangan Perkebunan." 2014. http://perkebunan.litbang.pertanian.go.id/pemanfaatan-kulit-kakaountuk-pakan-ternak/.

6. Direktorat Jendral Perkebunan. 2016. "Statistik Perkebunan Indonesia Komoditas Kakao 2015 - 2017." Jakarta.

7. Hui, Y.H., ed. 2006. Handbook of Food Science, Technology, and Engineering. 1st ed. Boca Raton: Taylor and Francis.

8. International Cocoa Organization. 2020. "ICCO Quarterly Bulletin of Cocoa Statistics XLVI, No. 2, Cocoa Year 2019/20," 2020.

9. Kamelia, Marlina, dan Fathurohman Fathurohman. 2017. "Pemanfaatan Kulit Buah Kakao Fermentasi Sebagai Alternatif Bahan Pakan Nabati Serta Pengaruhnya Terhadap Pertumbuhan Ternak Entok (Cairina Muschata)." Biosfer: Jurnal Tadris Biologi 8 (1): 66-77. https://doi.org/10.24042/biosf.v8i1.1264

10. Kuntari. 2006. "Optimalisasi Proses Desizing, Scouring, Bleaching dan Caustizing Secara Simultan Sistem Pad-Batch pada Kain Rayon Viskosa." Jurnal Sains Materi Indonesia, 118-23.

11. Lestari, Dwi Wiji, Vivin Atika, Isnaini Isnaini, Agus Haerudin, dan Tin Kusuma Arta. 2020. "Pengaruh pH Ekstraksi pada Pewarnaan Batik Sutera Menggunakan Pewarna Alami Kulit Kayu Mahoni (Switenia Mahagoni)." Jurnal Rekayasa Proses 14 (1): 74-81. https://doi.org/10.22146/jrekpros.54439.

12. Lutfinor. 2011. "Perbandingan Penggunaan Beberapa Jenis Zat Warna Dalam Proses Pewarnaan Serat Nanas." Jurnal Dinamika Penelitian Industri 22 (1).

13. Malimongan, Merlin, Nursiah La Nafie, and Paulina Taba. 2015. "Pemanfaatan Kulit Buah Coklat (Theobroma Cacao) sebagai Bioadsorben Ion Logam Ni (II)." Skripsi. Fakultas MIPA. Universitas Hasanuddin.

14. Mansour, Rym. 2018. Natural Dyes and Pigments: Extraction and Applications. Edited by Mohd Yusuf. Handbook of Renewable Materials for Coloration and Finishing. Scrivener Publishing LLC. https://doi.org/10.1002/9781119407850.ch5.

15. Padmitasari, Anastasia, dan Dewi Novitasari. 2010. "Pembuatan Serbuk Zat Warna Alami Tekstil dari Daun Jati dengan Metode Spray Dryer." Surakarta: Laporan Tugas Akhir. Teknik Kimia. Fakultas Teknik. Universitas Sebelas Maret.

16. Pristiwati E., Pujilestari T., Farida, Haerudin A., Salma I.R, Atika V., Lestari D.W., Jubaedah, Apriliani. 2016. Peningkatan Kualitas Batik Zat Warna Alam,. Jakarta: Badan Penelitian dan Pengembangan, Kementerian Perindustrian.

17. Puastuti, Wisri, dan IWR Susana. 2014. "Potensi dan Pemanfaatan Kulit Buah Kakao sebagai Pakan Alternatif Ternak Ruminansia." Wartazoa 24 (3): 151-59.

18. Pujilestari, Titiek, Farida Farida, Endang Pristiwati, Agus Haerudin, dan Vivin Atika. 2016. "Pemanfaatan Zat Warna Alam dari Limbah Perkebunan Kelapa Sawit dan Kakao sebagai Bahan Pewarna Kain Batik." Dinamika Kerajinan Dan Batik: Majalah IImiah 33 (1): 1-8. https://doi.org/10.22322/dkb.v33i1.1119. 
19. Purnamawati, Hening, dan Budi Utami. 2014. "Pemanfaatan Limbah Kulit Buah Kakao (Theobroma Cocoa L) sebagai Adsorben Zat Warna Rhodamin B." In Prosiding Seminar Nasional Fisika Dan Pendidikan Fisika (SNFPF), 5:12.

20. Razak, Nursyamirah Abd, Siti Marsinah Tumin, and Ruziyati Tajuddin. 2011. "Effect of Temperature on the Color of Natural Dyes Extracted Using Pressurized Hot Water Extraction Method." American Journal of Applied Sciences 8 https://doi.org/10.3844/ajassp.2011.45.49.

21. Satria, Yudi, dan Dwi Suheryanto. 2016. "Pengaruh Temperatur Ekstraksi Zat Warna Alam Daun Jati Terhadap Kualitas dan Arah Warna Pada Batik." Dinamika Kerajinan dan Batik: Majalah IImiah 33 (2): 101. https://doi.org/10.22322/dkb.v33i2.1628.

22. Sinaga, Anita Sindar. 2019. "Segmentasi Ruang Warna L*a*b." Jurnal Mantik Penusa 3 (1): 43-46.

23. Sofyaningsih, Mira, dan Iswahyudi. 2018. "Mikroenkapsulasi Ekstrak Kulit Buah Naga Merah dengan Teknik Spray Drying." Argipa 3 (1): 17.

24. Sudjadi. 1988. Metode Pemisahan. Yogyakarta: Kanisius Publisher.

25. Susanto, Sewan. 1973. Seni Kerajinan Batik Indonesia. Yogyakarta: Balai Penelitian Batik dan Kerajinan, Lembaga Penelitian dan Pendidikan Industri, Departemen Perindustrian.

26. Tama, Janur Bisma, Sri Kumalaningsih, dan Arie Febrianto Mulyadi. 2014. "Studi Pembuatan Bubuk Pewarna Alami dari Daun Suji (Pleomele Angustifolia N . E . Br .) Kajian Konsentrasi Maltodekstrin dan $\mathrm{MgCO}_{3}$." Jurnal Industria 3 (1): 73-82.

27. Utomo, Deny. 2013. "Pembuatan Serbuk Effervescent Murbei (Morus Alba L.) dengan Kajian Konsentrasi Maltodekstrin dan Suhu Pengering." Teknologi Pangan 5 (1). https://doi.org/10.35891/tp.v5i1.498.

28. Wulan, Siti Nursito. 2001. "Summary for Policymakers." In Climate Change 2013 - The Physical Science Basis, edited by Intergovernmental Panel on Climate Change, 2:1-30. Cambridge: Cambridge University https://doi.org/10.1017/CBO9781107415324.004. 